\title{
Empowering The Needy, Respecting Diversity: Insights From The Qur'ān
}

\author{
Izza Rohman \\ Universitas Muhammadiyah Prof. Dr. Hamka (UHAMKA) \\ izzarohman@uhamka.ac.id
}

\begin{abstract}
The issue of diversity and social empowerment might have often been addressed separately. However, the Qur'ān has talked about the two interlinkedly. There are many verses in the Qur'ān that suggest people to get involved in the giving and empowerment of the needy and at the same time to respect diversity.

This study seeks to explore how the Qur'ān has balanced its message on respecting human diversity and that on helping those in need, by identifying the relevant verses and how some of these verses have been interpreted by classical and modern exegetes. The identification of the verses would be mainly based on a search for the use of words relevant to kinds of people in need of help: the needy

(faqīr), the poor (miskin), the orphans (yatīm), the beggars (s $\left.\bar{a}^{\prime} i l\right)$, the deprived (mahrūm), the wayfarer (ibn sabīl), the captive (asīr), the slave (raqabah), the ill

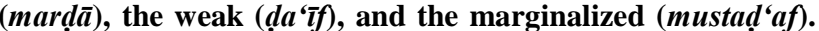
Qur'ānic exegeses surveyed are seven commentaries representing classical and modern exegeses and representing various methods of interpretation.

The Qur'ān clearly demands respect for the people in need regardless of their background, providing insights to to hold social services with respect for diversity. This is particularly built upon its messages on humility, sincerity, and understanding in actions of social service.
\end{abstract}

Keywords: Qur'an interpretation, social empowerment, respect of diversity.

\section{INTRODUCTION}

The teachings of the Qur'ān on helping the poor and the needy have been often underlined in Muslim discourse. On the other hand, its teachings on respect for diversity (of any kind) have also been frequently addressed in previous studies. However, there is a lack of discussion around how the Qur'ān relates the two. As a result, talks about Islamic teachings on diversity are more often linked with tolerance, multiculturalism and pluralism, while discussions on Islamic teachings on helping the deprived and disadvantaged people usually do not emphasize the need for respecting diversity.

In fact, the Qur'ān hints at the need for respecting diversity while urging people to empower the people in need. This paper seeks to reveal the ways by which the Qur'ān may inspire social and economic empowerment of the people in need that is fully respectful of diversity. In particular, the paper highlights some verses of the Qur'ān that address both issues of empowerment and diversity interlinkedly.

\section{METHODS}

To explore how the Qur'ān has balanced its message on respecting human diversity and that on helping those in need, this study starts with the identification of verses relevant to kinds of people in need of help: the needy (faqīr), the poor (miskin), the orphan (yatim), the beggar ( $s \bar{a}$ 'il), the deprived (mahrūm), the wayfarer (ibn sabīl), the captive $(a s \bar{\imath} r)$, the slave (raqabah), the ill (mardā), the weak ( $\left.d a^{\prime} i f\right)$ ), and the marginalized (mustad'af). After the verses being listed, only verses that are relevant to respect for diversity are dealt with.

To confirm and explore the topic of respect for diversity implied in the verses, some Qur'anic exegeses are surveyed. Qur'ānic exegeses consulted here are seven commentaries representing classical and modern exegeses, and at the same time representing various methods of interpretation (and also various theological backgrounds). They are the tafsīrs of: al-Zamakhsharī (classical; known for its heavily linguistic approach; Mu'tazilī) [1]; al-Rāzī (classical; basically reason-based but known for its theological and logical approach; Ash'arī) [2]; Ibn Kathīr (classical; tradition-based; Sunn̄̄-Atharī) [3]; al-Biqā' ${ }^{`} \overline{1}$ (classical; coherencebased; Ash'arī) [4]; Ibn 'Āshūr (modern, mixing linguistic, contextual, coherencebased and jurisprudence-based approaches; Ash'arī) [5]; alShanqītî (modern; known for its cross-referential approach; Sunn̄̄ with Salafì leaning) [6]; and al-Ṭabāțabā'̄̄ (modern; mixing intertextual and tradition-based approaches; Twelver Shī'ī) [7] . It should be noted, however, that this study is not to compare these commentaries, rather than to see them as complementing each other.

\section{RESULT AND DISCUSSION}

The Qur'ān has outlined basic rules for giving. Surveying its verses, one knows that the Qur'ān teaches respect for the needy while empowering them on three levels: 1) the perception of what we give to them; 2) the quality of what we give to them; and 3) the way we communicate with those we give.

Firstly, the Qur'ān teaches us to perceive what we give to the people in need as a haqq (see Q 17:26; 30:38; 51:19; 70:24). Haqq is translated as "right" [8], [9], [10] "share" Qarai [11], "due" [12], [8], [13], [11], [10] "due right(s)" [10], or "due share" [12], [13].

While the word appears repeatedly in the Qur'ān in various meanings, when it deals with the wealth that should be shared to the needy, the word haqq used in the Qur'ān is 
often understood as haẓz, nașīb, qadr, miqdār, or juz ‘ (portion/share). However, the Qur'ān itself never use these words in relation to the things that should be shared to the needy. This could mean that the word haqq implies a different connotation.

While interpreting Q 51:19, Ibn 'Āshūr explains that the word haqq in this context might imply that it is an obligation from Allah or that it is something that a believer oblige himself. Al-Zamakhsharī [1] said similar view when commenting on Q 70:24 [1]. However, while interpreting Q 70:24, Ibn 'Āshūr [5] clearly said that it is named haqq to indicate that the observers of prayer see the petitioner (sā'il) and the deprived (mahrūm) as if both are the coowners of their wealth. Therefore, the usage of haqq could be to imply that a believer should consider what he gives to the people in need as their own and not his own; as their right not as his right [5].

This notion that a giver should have such a view is also implied in the use of the word ta ' $\bar{a} m$ (food) to mean it 'âm (feeding) in several places of the Qur'ān (see Q 2:184; 69:34; 89:18; and 107:3). While interpreting Q 107:3, both al-Rāzi and al-Ṭabātabā' $\overline{1}$ [2] note that the use of the phrase ta'àm al-miskin (the food of the poor) to mean it 'àm almiskīn or it 'ām ta 'àm al-miskīn (feeding the poor) implies that the food we give to the poor is actually their own right. Similarly, when interpreting Q 107:3 and Q 69:34, alBiqā' $\overline{1}$ said that the use of ta ' $\bar{a} m$ instead of $i t^{\prime}$ ' $\bar{m} m$ is to imply that there is a portion in the wealth of the haves that becomes the right of the have nots. It is to imply that the latter is essentially the real owner of the portion. While interpreting Q 89:18, al-Biqā' $\overline{1}$ states that the poor is the coowner of the wealth of the rich as much as what the latter should spend as zakāh (almsgiving) [4].

Perceiving what we give to the poor as their right means that we should not be proud of ourselves with the very act of giving. Instead, we should give them due respect and pay due service to them.

Secondly, the Qur'an teaches us to give good things we like. We are expected to give from that which we love $(\mathrm{Q}$ $3: 92 ; 2: 177$; and 76:8). We are not expected to choose the defective things, which we ourselves do not like (Q 2:267). In spite of love for it, we should give food and wealth to the needy (Q 2:177; 76:8). This means that we should love them more than our own wealth. We should give respect to them by giving them what we like, and not what we dislike. At least, what we give should be equal to the average food we give to our families (Q 5:89). Loving them more than our own wealth indicates that we love Allah more than our wealth. Because, giving the people in need is in fact spending in the cause of Allah (fì sabīl Allāh), and therefore one should give what we love in His way.

While commenting on Q 3:92, Ibn 'Āshūr [5] argues that giving the wealth we love is fundamentally important to the society as it could strengthen the bonds of brotherhood among the people. To give them what we love is like treating them as brothers [5].

This brotherhood may go beyond difference in faith. Q 76:8-9 mentions that the believers are expected to feed the poor, the orphans, and the captives, in spite of their own love for the food, and without expecting any reward. This call to Muslims to feed their captives (prisoners of war) indicates that even Muslims' enemies (the disbelievers) deserve due respect as human beings despite their different faith. Even difference in faith should not be an obstacle for our kindness.

Thirdly, the Qur'ān teaches us to build good communication and understanding with those in need. For instance, believers are prohibited to follow up their charity with reproaches and affronts (Q 2:262-264; Cf Q 4:8). Kind speech (qawl ma'rūf) in response to the needy and forgiving their annoyance (maghfirah) is better than a charity followed by injury (Q 2:263). Al-Zamakhsharī argues that $\mathrm{Q} 2: 262$ shows that avoiding reproaches (mann) and affronts $(a d h \bar{a})$ is more important that the charity itself.[1] In line with this, al-Zamakhsharī, al-Rāzī, and alṬabātabā' $\overline{1}$ understand the subsequent verse (Q 2:263) as implying that refusing to give with kind speech (e.g. prayer etc.) is still better than giving but following it with impolite speech or injury. Ibn Kathīr, while interpreting Q 2:262, narrated a report that the Prophet said, "No charity that Allah loves more than kind speech." Similarly, al-Rāzī, while interpreting Q 2:262, said that the verse shows that reproache and injury are among major sins as both can annihilate the big reward of a good deed [2].

Similar messages have been repeatedly addressed in the Qur'ān, even in some verses revealed very early, such as Q 93:9-10; 89:17; and 107:2, which suggest the importance of honoring the orphan, the poor, and the beggar. Moreover, the need to build good communication with the people in need is also implied in the command of doing kindness (ihsānn) to parents, relatives, orphans, the poor, the neigbor, the companion, the wayfarer and "those whom your right hand possess", which is immediately followed by a statement that Allah does not like those who are self-deluding and boastful (Q 4: 36). In another verse, the same message is immediately followed by a command to speak to people good words (husn) (Q 2:83).

The Qur'ānic message of speaking to the needy words of appropriate kindness (qawl ma' $r \bar{u} f$ ) can mean that we need to respect the people in need we try to empower regardless of their backgrounds of gender identity, color, race, ethnicity, national origin, age, marital status, profession, political belief, religion, immigration status, mental or physical disability, and so on and so forth.

This message could also mean that the rich should not act as those who know more and know better than those in need. Having this attitude contradicts the prohibition of any reproach and injury following charity (Q 2:262-264). While interpreting Q 2:263, Ibn 'Āshūr cites al-Ghazālī who said that the injury stems either from dislike of giving wealth or from an assumption that oneself is better than the needy. The latter is caused by one's ignorance about the danger of fortune and unawareness that people's rank is not determined by how much fortune they have [5].

\section{CONCLUSIONS}

There are various verses in the Qur'ān that give us insights to hold social services with respect for the people in need regardless of their background. The socialeconomic empowerment of those in need should be accompanied with humility, sincerity, and understanding. The clear, repeated messages of the Qur'ān on humility, sincerity, and understanding in actions of service to 
humankind imply that respect for diversity is a must in any social work service. This should suffice to inspire the development of social work profession in Muslim societies. While this study focuses on the need for treating the needy with kindness irrespective of their background, it has hinted at many verses of the Qur'ān that could be part of the foundations of Islamic perspectives on social work, which deserve future research.

\section{REFERENCES}

[1] A. al-Q. M. ibn'Umar al-Zamakhsharī, al-Kashshāf 'an Haqā'iq Ghawāmid̆ al-Tanzīl wa 'Uyūn al-Aqāwīl fì Wujūh al-Ta'wīl. Cairo: al-Mațba'ah al-'Āmirah al-Sharqīyah, 1307.

[2] F. al-Dīn al-Rāzī, Mafātīh al-Ghayb. Beirut: Dār al-Fikr.

[3] I. Ibn Kathīr, Tafsìr al-Qur'àn al-'Azīm. Cairo: Mu'assasah Qurțubah \& Maktabat Awlād al-Shaykh li al-Turāth, 2000.

[4] I. ibn 'Umar al-Biqā̄î̀, Naẓm al-Durar fì Tanāsub al-Āyāt wa alSuwar. 1984

[5] M. al-Ṭāhir Ibn 'Āshūr, Tafsìr al-Tahrīir wa al-Tanwīr. Tunis: alDār al-Tūnisīyah li al-Nashr, 1984.

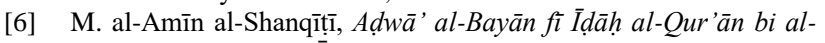
Qur'ān. Mecca: Dār 'Ālam al-Fawā'id. al-Ṭabāțabā' $\overline{1}, 1426$.

[7] M. H. al-Ṭabātabā'̄i, al-Mīzāan fì Tafsìr al-Qur'ān. Beirut: Mu’assasat al-A‘'lamī li al-Mațbū'āt, 1997.

[8] M. T.-D. Al-Hilâlî and Muhammad Muhsin Khân, Translation of the Meanings of the Noble Qur'an in the English Language. Madinah: King Fahd Complex for the Printing of the Holy Qur'an.

[9] Saheeh International, The Qur'ān: English Meanings. Jeddah: AlMuntada Al-Islami., 1997.

[10] A. Y. Ali, The Holy Qur-ān: English Translation of the Meanings and Commentary. Madinah: ing Fahd Complex for the Printing of the Holy Qur'an.

[11] 'Ali Quli Qara'i, The Qur'an With a Phrase-by-Phrase English Translation. London: Islamic College for Advanced Studies Press, 2004.

[12] M. Asad, "The Message of the Qur'an." [Online]. Available: http://muhammadasad.com/Message-of-Quran.pdf (accessed October 2017).

[13] M. Pickthall, The Meaning of The Glorious Koran. New York: Alfred A. Knopf, 1930. 